\title{
PSYCHELIA AND VISIONARY ART THE WORK OF ART AS THE RESULT OF INTERACTION BETWEEN CULTURE AND NON-ORDINARY STATES OF CONSCIOUSNESS
}

\author{
Arte visionária e psicodelismo obras artísticas resultantes da interação entre cultura e estados \\ não ordinários de consciência ${ }^{1}$
}

\author{
José Eliézer Mikosz² \\ Artista interartes, pesquisador em arte visionária, professor adjunto da Unespar Campus Curitiba \\ antarm@gmail.com
}

\begin{abstract}
This essay investigates the poetics of visionary art as a result of interactions between local cultures and non-ordinary states of consciousness. We seek, through brief examples, to draw a parallel between images produced in the past, images produced by Amazonian tribes, and the production of contemporary artists and to point out series of meaningful coincidences between them. Despite local cultural differences, it is possible to observe similar patterns of non-ordinary states of consciousness in the context of artistic works; at the same time, such an approach also brings up a whole historical background to the current and so called - visionary art. $^{3}$
\end{abstract}

Keys-words: visionary art; myths; religion; non-ordinary states of consciousness.

RESUMO: Esse artigo investiga a poética da arte visionária como resultado da interação entre culturas locais e estados não ordinários de consciência. Através de alguns exemplos foi buscado traçar um paralelo entre imagens produzidas no passado com outras de tribos amazônicas e a produção de artistas contemporâneos, apontando várias coincidências significativas entre elas. Apesar das diferenças existentes entre culturas locais, é possível observar padrões similares, no contexto de obras artísticas, encontrados entre elas advindas de estados não ordinários de consciência; ao mesmo tempo, essa abordagem traz também uma base histórica para o que se chama atualmente de arte visionária.

Palavras-chave: arte visionária; mitos; religião; estados não ordinários de consciência.

\footnotetext{
${ }^{1}$ Este artigo foi resultado de apresentação realizada na Greenwich University em Julho de 2013 durante o Breaking Convention em Londres.

2 Escola de Música e Belas Artes do Paraná/EMBAP. Editor da Revista Internacional Interdisciplinar Art\&Sensorium da mesma instituição. Doutor pelo Programa de Pós-Graduação Interdisciplinar em Ciências Humanas (PPGICH-UFSC). Faz parte da equipe de organização do Research Centre for the Study of Psycointegrator Plants, Visionary Art and Consciousness (WASIWASKA). É associado ao Núcleo de Estudos Interdisciplinares sobre Psicoativos (NEIP). Tem experiência na área de Artes, com ênfase em Pintura, atuando principalmente nos seguintes temas: artes visuais, arte visionária, artes plásticas, estética e relações inter e transdisciplinares entre arte e consciência.

${ }^{3}$ We have chosen to use the expression "non-ordinary states of consciousness" instead of "altered states of consciousness", because we understand that it is an "alteration", but another level of consciousness with its own characteristics; besides, the expression "altered states" still carries cultural depreciatory meanings, as if something malformed or pathological, which does not correspond in any sense with the investigation of this research.
} 


\title{
Religious Experience and Myths
}

Experiences of entering into non-ordinary states of consciousness can take us to a world different from the ordinary, material and rational world of our everyday life, therefore many times associated with a "spiritual realm". Some advocate the real existence of such realm; others, however, may consider that it is nothing more than characteristic reactions of our nervous system. It is possible to divide this type of experience into two distinctive forms. The first consists in the direct contact of the individual with this spiritual realm. This is probably the case of many avatars and prophets since the ancient ages, religious founders, priests and/or shamans.

The other form is the one experienced by disciples. They "believe" in those spiritual leaders, not merely due to their innocence and unpreparedness, fears and doubts in face of a mysterious life they are not able to explain, but also because, somehow, they feel within themselves a resonance of what is conveyed by those masters, thus giving them confidence and coherence as stated by Campbell:

\begin{abstract}
Any person who engages with the work of literary creation knows that we open up ourselves, it is a kind of surrender, and the book talks to us and builds itself. To some extent, you become the conveyer of something that was transmitted to you from what is called the Muses, or, in biblical terms, "God". This is not a manner of speaking, this is a fact. Once the inspiration results from the unconsciousness, and once the mind of the people of any small society has much in common with what the unconsciousness is concerned, what the shaman or the prophet brings to light is something that exists latent in anyone, just waiting to be brought to light. (CAMPBELL 1991, p.71)
\end{abstract}

It is very likely that certain myths, for instance, some indigenous legends, have emerged from visions received in non-ordinary states of consciousness. However, in time, they may suffer alterations and adaptations according to transformations of time and local culture, deviating them, apparently, of the initial associations, or even being substituted by symbolic synonyms, in other words, different images with the same meaning:

Well, automobiles entered mythology. They entered the dreams. And aircrafts are long in service of imagination. The flight of the aircraft, for instance, acts in the imagination as a liberation from earth. It is the same thing with birds, in a certain way. The bird is a symbol of the liberation of the spirit in relation to its earth's imprisonment, in the 
same way that the serpent symbolizes the earth's imprisonment. The aircraft plays this part nowadays. (CAMPBELL 1991, p.32)

A myth, as a sacred account about creation, told by a people can sound funny to others: what is sacred for some people, it is superstition for others, but this does not reduce the power and efficiency of the myth in its place of birth (Lewis-Williams \& Pearce 2005, p.150). Myths are inserted in the society, people inherit them and assimilate the culture in which they were born. People would feel bad and ridiculous should they be obliged to dress, or undress, according to practices and customs of a culture different from their own. Similarly, the individual absorbs the religion available around them, becoming a Christian, Jewish, Muslim, Hindu, or Huichol.

A deep study of these characteristics is something very complex, but it is possible to find some examples to illustrate the question. To begin with, we will study some characteristics of the human mind while in non-ordinary states of consciousness, and, in parallel, we will show some attempts to make visual representations of these experiences by some individuals.

\section{Shamanism and Non-ordinary States of Consciousness}

What would be the main characteristic one could notice in spiritual phenomena? The answer is that they seem to be linked to the human ability of changing their states of consciousness through what we will thus call shamanic-spiritual techniques or psychedelic techniques. Many of them are well-known and used by various religions: meditation, fast, celibacy, privation of senses, stimulation of the cerebral visual cortex by stroboscopic lights, ${ }^{4}$ yoga, tantric, usage of plants and psychoactive substances, chanting of mantras and prayers, physical exhaustion, sacred dances, usage of specific music that ranges from shamanic drums and maracas, to modern electronic music. The non-ordinary states of consciousness cover a series of characteristics, such as the contact with different levels of reality that are beyond both rational process and material world; however, what precisely interests us in this study are the visual phenomena that some of those techniques can facilitate, in other words, what those techniques can cause in terms of visual stimuli - generally called, in a reductive way, hallucinations - and the production of visual arts as a result of those experiences.

\footnotetext{
${ }^{4}$ As in the experiments conducted by Dr. Dominic F. Fytche in the King's College Institute of Psychiatry
} in London. 
Huxley, in The Doors of Perception, 1957, observes that the brain seems to work as a reducing valve of perception, a filter for reality, "to make possible biological survival" (Huxley 2004, p.32). Our consciousness receives a torrent of impressions from the outer world and our own body that needs to be filtered. In fact, we are not simultaneously aware of all the stimuli coming from our senses. What comes to our consciousness must, as it were, follow a hierarchy of priorities.

In the same way that the outer world impressions are filtered, the inner impressions, in other words, the memories, thoughts and unconscious contents, must go through some kind of selection. In "normal conditions", people relate to the world through this filtering. However, shamanic-psychedelic-spiritual techniques can avoid this filtering, and, in some cases, even intensify the brain reception of certain impressions coming from the outer or inner world. Hancock, about some probable brain characteristics, says:

Theoretically the brain could be as much a receiver as a generator of consciousness, and thus might be fine-tuned in altered states to pick up wavelengths that are normally not accessible to us. (HANCOCK 2007, p.39)

The shamanic practices are associated to the non-ordinary states of consciousness and are very old and similar among people of different parts of the world, a reason why some researchers use the expression shamanic state of consciousness (Harner 1982, p.59). In this state it is possible to observe the spectrum of consciousness divided into three stages (Lewis-Williams 2004, p.125): Stage 1, of entoptic phenomena, visual phenomena that occur between the eye and the cortex, independently of the material world, but that can be projected on outer world objects. These patterns usually consist of a variety of geometric, colorful and luminous forms in a fractal combination. Klüver divides the entoptic phenomena into four categories, also called form constants or phosphenes: ".(i) gratings, lattices, fretworks, filigrees, honeycombs and chequer-boards, (ii) cobwebs, (iii) tunnels, funnels, alleys, cones and vessels, and (iv) spirals" (Klüver 1966, p.66). Lewis-Williams identifies seven types of categories: 1. a grid and its development into a lattice or expanding hexagon pattern, 2. set of parallel lines, 3. bright dots and short flecks, 4. zigzag lines, reported by some subjects as

\footnotetext{
${ }^{5}$ Pressing the ocular globe with the fingers is a way of stimulating the vision of phosphenes.
} 
angular, by others as undulating, 5. nested catenary curves, the outer arc of which comprises flickering zigzags (well known to migraine sufferers as the 'fortification illusion'), 6. filigrees, or thin meandering lines, 7. spirals (vortex), we can identify these patterns since rupestrian art; Stage 2, or construal, which can be understood as a process of interpretative construction: in this stage, the individual tries to make sense out of the entoptic forms - what can happen in a similar way to when one observes undefined or ambiguous images, such as spots, cloud formations, folds of fabric, which can be transformed into familiar shapes, such as animals, people, faces, etc, according to propensity, cultural aspects, and many momentary influences. For example, when we look at the sequence of colon, hyphen, and parenthesis and we see a smiling face. ${ }^{6}$ By getting closer to stage 3 , the experience with vortex or tunnels, with shinning light on the background, is common and it is often associated with the near-death experience. It is at this point that "[...] many individuals report experiences with vortex or a spinning tunnel that seems to encircle and attract them to its bottom" (Horowitz 1975, pp.15395). Tunnels seem to be related to certain brain structures; the article Geometric Visual Hallucinations, Euclidean Symmetry, and the Functional Architecture of Striate Cortex describes a mathematic investigation about the possible origin of these images, assuming that the connection patterns between the retina and the striate cortex (V1) the retino-cortical pathway - and the neural circuits in V1, local and lateral, are what determine these geometries (Bressloff at al 2001). Finally, Stage 3, the "hallucinations", in other words, visions in which more complex scenes are formed. The individual is not always able to draw a distinction between their experience and the material world. Complete visions of all kinds can be formed, bizarre somatic sensations can happen, such as physical deformations, transfigurations into animals and plants, or others.

This division in stages does not mean that people necessarily go through all of them, nor that the passage from one stage to another has rigid boundaries - on the contrary, the passage happens gradually. Cultural information can influence the individual's expectations and interests, and accentuate one stage or another.

\footnotetext{
${ }^{6}$ :-) This characteristic of associating ambiguous shapes to known objects is called pareidolia.
} 


\section{Visionary Art}

What is Visionary Art? Briefly we can say that the Visionary Art is an art where the production is subject to the resulting experiences of non-ordinary states of consciousness (MIKOSZ 2009, p.114).

The visions experienced in non-ordinary states of consciousness are usually perceived as genuine by individuals, even by those who are not shamans. They are experiences of "another world", which can only be translated into "this world" in a descriptive and symbolic way, mediated by each individual's culture and internal repertoire. This is a fundamental point, for it demands a profound reflection on how we understand the foundations of religious faith. Depending on cultural influences, language, expectations and personal preferences, the individual's emotional state, environmental circumstances, in short, contingent elements known under the expression set and setting, ${ }^{7}$ the experience can be guided as to what will be experienced or seen, respecting certain limits of possibility. For instance, the vision of a spiral can acquire depth as a vortex or a tunnel. The images can also be seen multiplied (poliopsia) and/or in integration with other objects in the scene, as it happens in the geometric drawings of people and animals, arisen from visions, which the Tukano people perform on their canoes (Lewis-Williams \& Pearce 2005, p.275). The vision of spirals and their various associations in each culture, such as snakes, labyrinths, circles, tunnels, ladders, follow similar principles of transformation (Mikosz 2009, p.114). It should be noted here that, even though this paper is mainly focused on visual phenomena, various sensations, not only the visual ones, are present in the non-ordinary states of consciousness.

In the case of the cosmological experience, "the shamanic technique par excellence consists in the passage of one cosmic region to another, from Earth to Heaven or from Earth to Hell". Shamans perform this through a structure that is part of the Universe and that connects this "layered cosmos": the axis mundi, the axis of the world, or yet, the cosmic pillar, which goes through a "doorway", a "hole", from where the gods, the dead, the shamans can ascend and descend on their celestial or infernal trips (ELIADE 2002, p.287).

The images below show some examples of the aforementioned entoptic elements, both in representations of indigenous peoples of the Amazon forest (Tukano

\footnotetext{
${ }^{7}$ The term was coined by Norman Zinberg.
} 
and Shipibo) as well as in the work of two artists from Western art history (Bosch and Blake), and of some visionary contemporary artists that the author had access to.

The Barasánas (Tukano family), indigenous people who use the Ayahusca in their rites, refer to images of vertical wavy parallel lines ( $17^{\text {th }}$ pattern in the chart below) which are part of Type 4 of the seven most recurrent shapes previously mentioned undulating zigzags - as symbolizing "[...] the creative thought and, sometimes, the energy of the solar creator itself'. An arch, $14^{\text {th }}$ pattern, with many colorful parallel lines of Type 5, can symbolize the Rainbow and, in one of the interpretations, the Father-Sun's Penis. The San people from South Africa enter a state of trance through dances. They concentrate on bright lines of Types 2 and 6 , which they believe to be filaments of light by which they climb, or along which they fluctuate towards the Great God in heaven (Lewis-Williams \& Pearce 2005, p.49). The $10^{\text {th }}$ pattern, a spiral of Type 7 , represents incest and forbidden women.

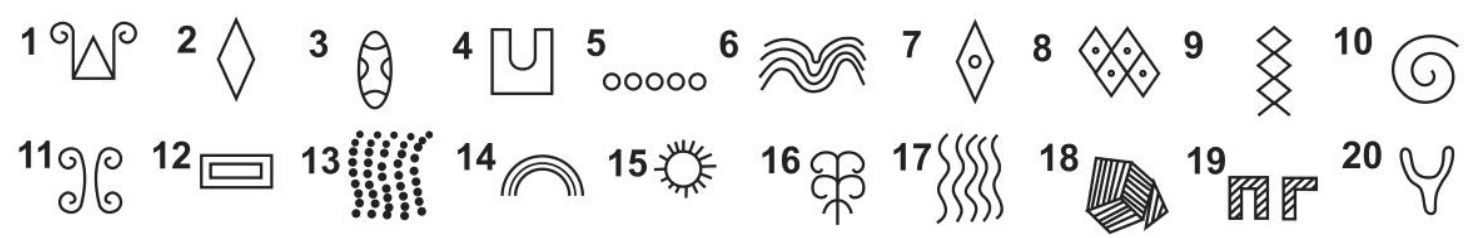

Figure 1. Codified drawings of the Barasána people in Brazil. Drawing by the author based on ReichelDomatoff (1978).

The painting Ascent of the Blessed, by Hieronymus Bosch, depicts a tunnel the souls pass through on their way to Heaven. Individuals who have undergone near death experiences report similar images of tunnels with a blue light irradiation at the end.

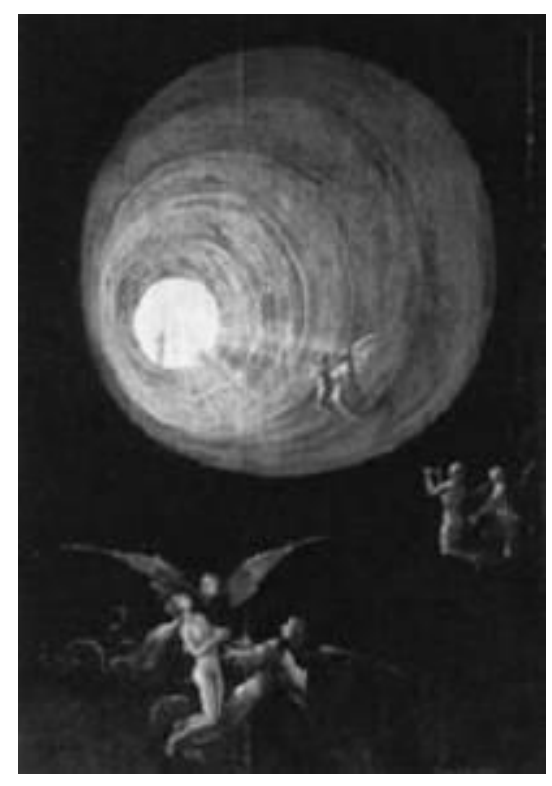


Figure 2. Ascent of the Blessed - in detail. Hieronymus Bosch (1450-1516).

Another way of representing these passages are the images of stairs that go from earth to the sky like in the painting Jacob's Dream by William James, based on the description of Jacob's vision in the Bible, where angelical beings go up and down these stairs. In a different and syncretic culture between shamanic elements and Christianism, the same idea can be represented differently like in the painting Spirits Descending on a Banco, by Peruvian painter Pablo Amaringo, where spirits go up and down not using stairs, but by way of a blue light spiral, intermediated by the figure of a Shaman (Banco). In the Amazon forest, the trees often represent a symbol of the axis mundi for the peoples who live there, since stairs are not common in that environment and therefore are not part of the peoples' imagination like in other cultures.

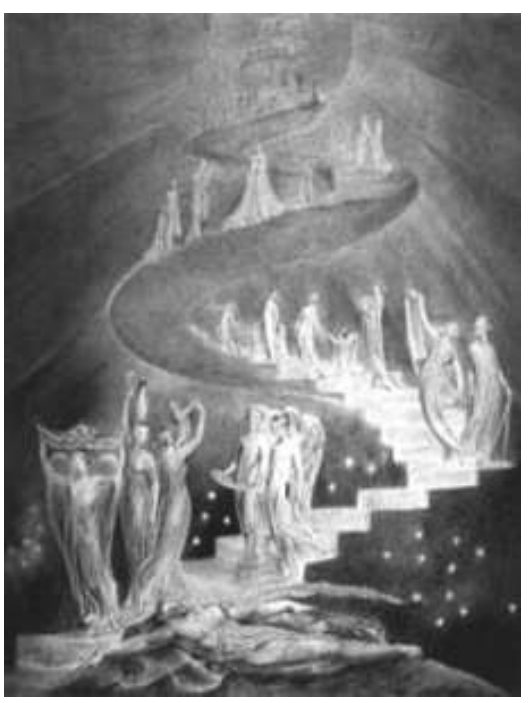

Figure 3. Jacob's Dream. William Blake (1757-1827).

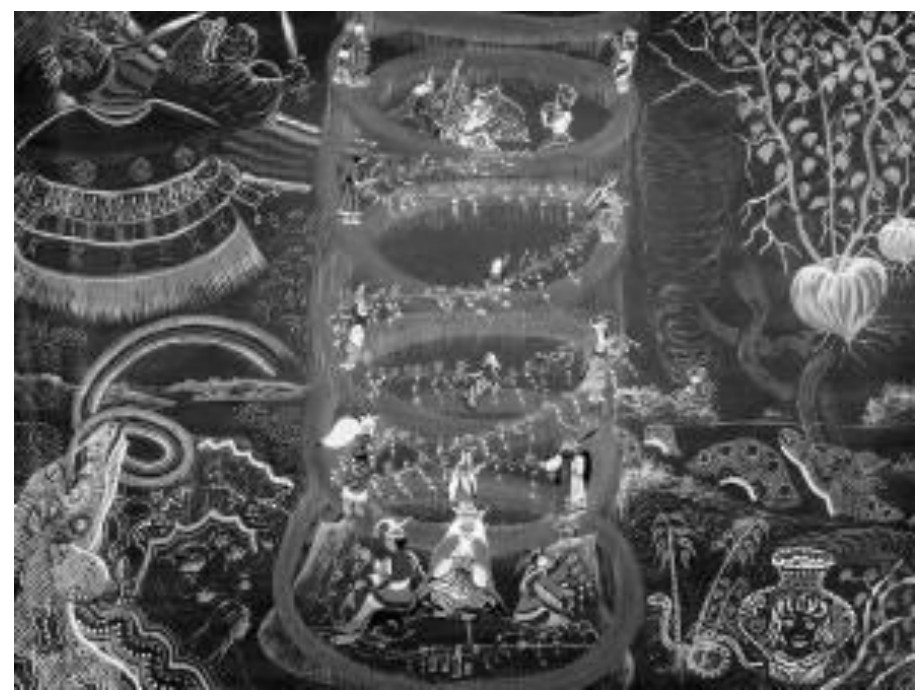

Figure 4. Spirits Descending on a Banco (medium). Pablo Amaringo (1938-2009).

Tunnels, stairways, ziggurats, towers (like the Babel Tower described in the Bible, built with the purpose of reaching Heaven), just like mountains, represent this ascent toward the spiritual realm. The image below, by artist Daniel Mirante, shows this sense of ascent and of the sacred in the painting Song of Vajra. 


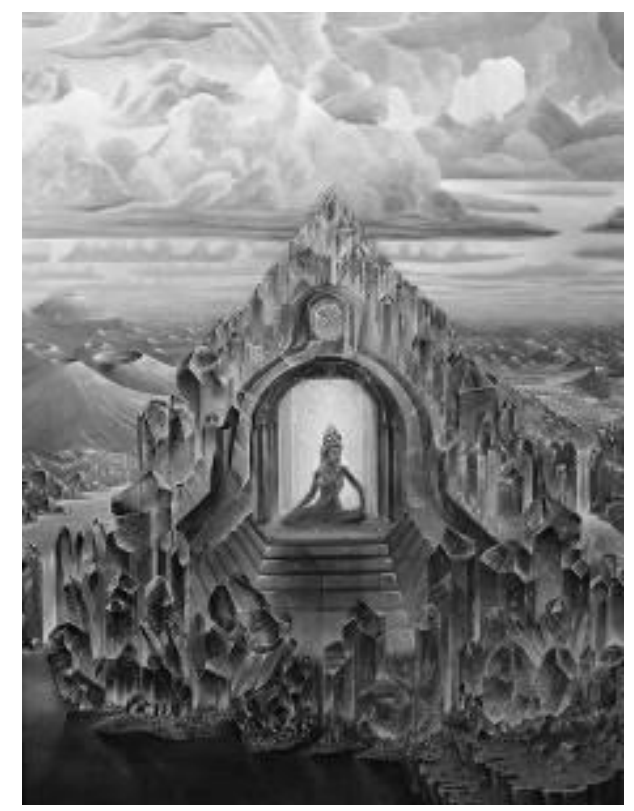

Figure 5. Song of Vajra. Daniel Mirante.

The Shipibo-Conibo Indians, native to the Peruvian Amazon, work with geometrical patterns that include catenary curves (Type 5) that end in little spirals (Type 7), zigzags (Type 4) that create a continuous background pattern like filigree (Type 6). These patterns are embroidered on a variety of fabrics, appear on pottery, body painting, ceremonial garments, among others. They may be simply drawn with black ink or in several colors, with small changes in the resulting patterns.

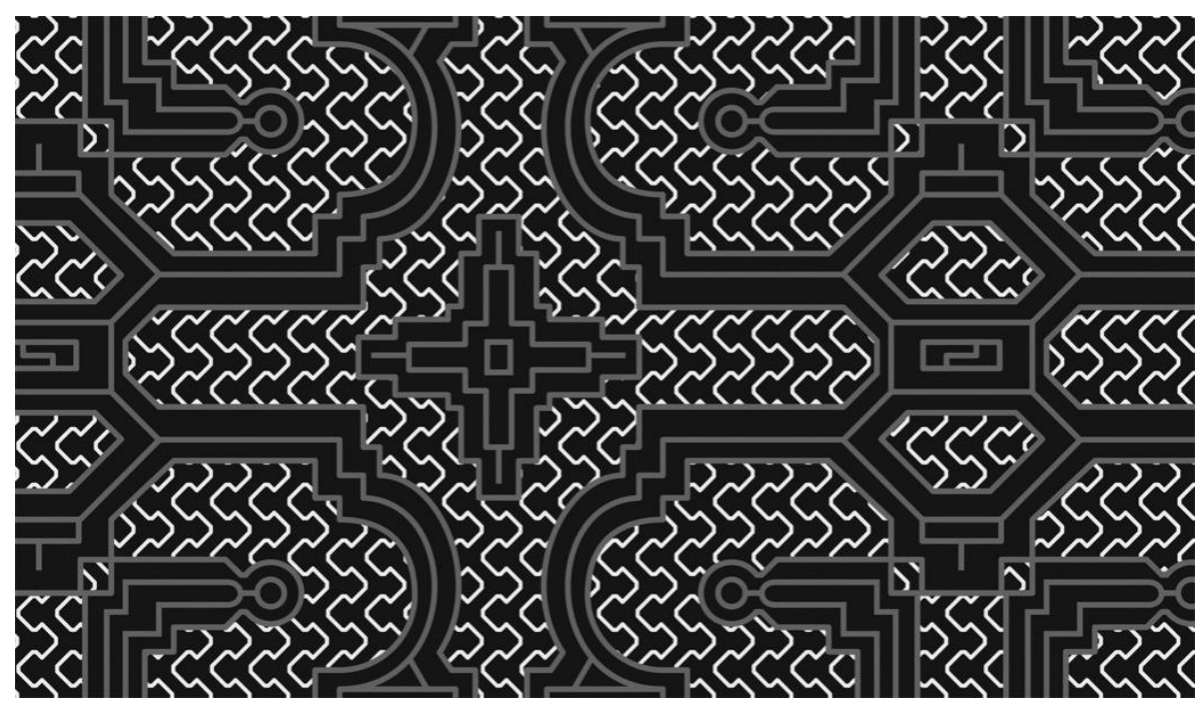

Figure 6. Shipibo-Conibo pattern. 
A similar pattern was used by the visionary artist, professor, and writer Laurence Caruana, the current director of the Vienna Academy of Visionary Art, in Austria. ${ }^{8}$ In the painting Vine of the Dead, Caruana used a similar pattern as a background for the image of Christ; he comments:

Then, during an all-night ceremony led by Native peoples, I ingested ayahuasca for the first time. Over the course of six hours, I reviewed my life, confronted my own death, and experienced a kind of personal Last Judgment. Toward early morning, this personal vision-quest transformed into a more archetypal vision. Wherever I turned my eyes, I saw the sacred patterns which constitute (so it seemed to me) the interconnected space and substance of our very souls. Weeks later, I was amazed to discover that the Shipibo-Conibo tribes of the Amazon, who treat ayahuasca as a sacrament, sew these same patterns onto all their ceremonial vestments, recognizing them as 'patterns of the soul'. (Caruana 2006)

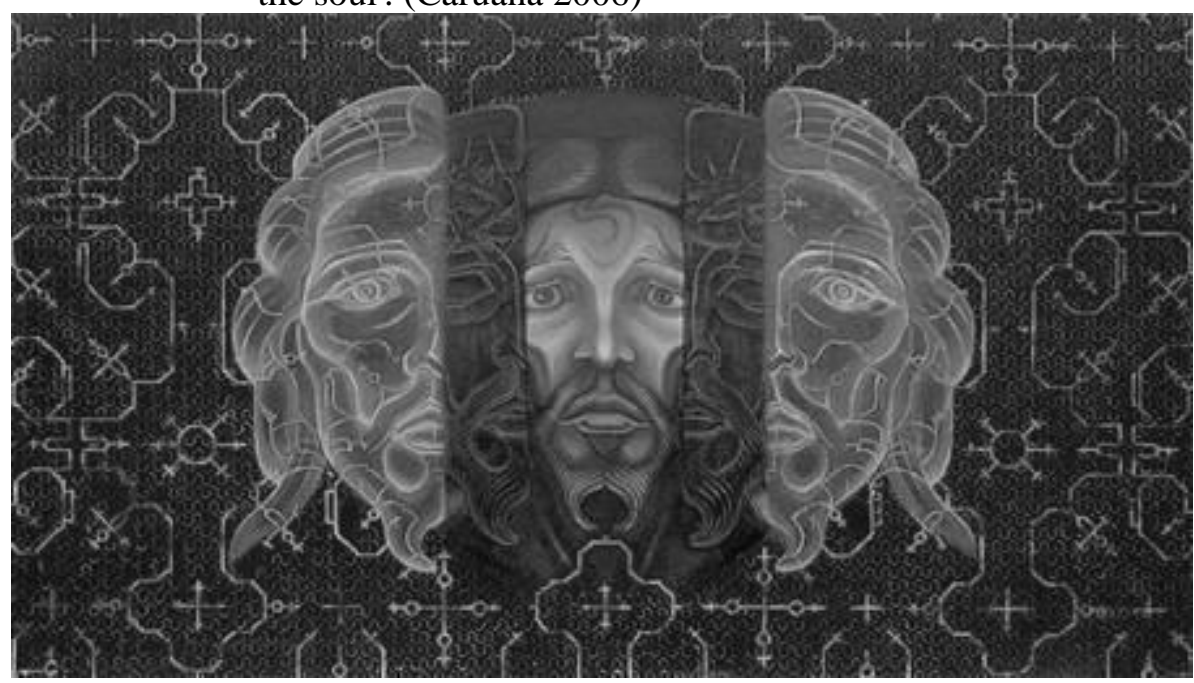

Figure 7. The Vine of the Dead. L. Caruana.

Parallel lines (Type 2), zigzag undulating lines (Type 4), and nested catenary curves (Type 5) can be found in many visionary works like Amanda Sage's paintings. Limbic Resonance, below, shows two figures in synchrony and communion amidst vibrations and energy exchange symbolized by luminous lines conveying the idea of an harmonious-amorous whole, states also associated with forms of spiritual communion typical of certain non-ordinary states of consciousness.

\footnotetext{
${ }^{8}$ More about the academy: <http://academyofvisionaryart.com/>.
} 


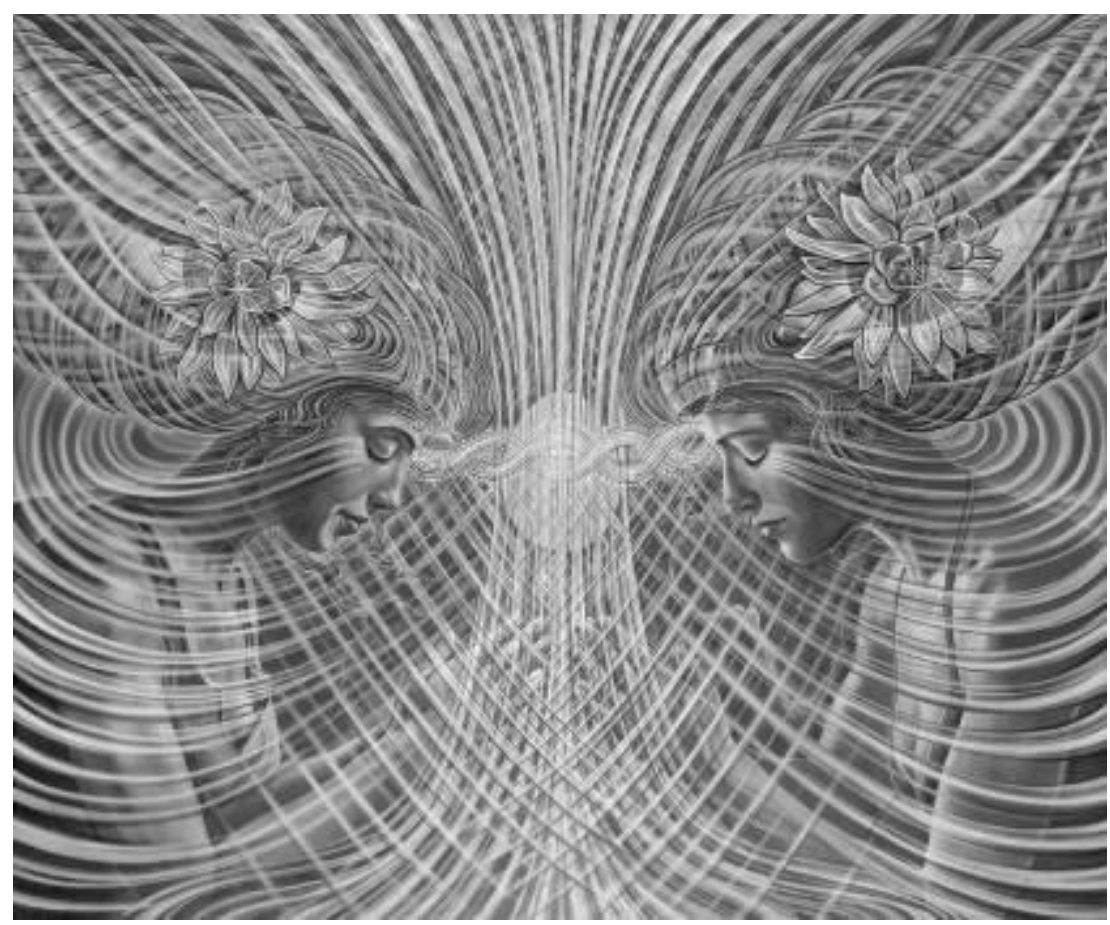

Figure 8. Limbic Resonance. Amanda Sage.

In many of the works by artist Andrew Gonzales, spirals and vortexes (Type 7) are present, usually transformed or merged with feminine figures. As previously seen, the spirals may represent the idea of passage, just as labyrinths, mandalas, tunnels and stairs that, in fact, are not just images seen during visions, but may also be sensorially experienced in several ways by an individual during non-ordinary states of consciousness. Another very common element associated with spirals is water. Actually, the association of water as a primordial element of creation is present since ancient Egypt. It is common to find spirals as a symbol of creation, water and lunar fecundity, associated with the feminine, the mother, the sea (CHEVALIER \& GHEERBRANT, 1999 p.398), all harmoniously present in the work of the artist. 


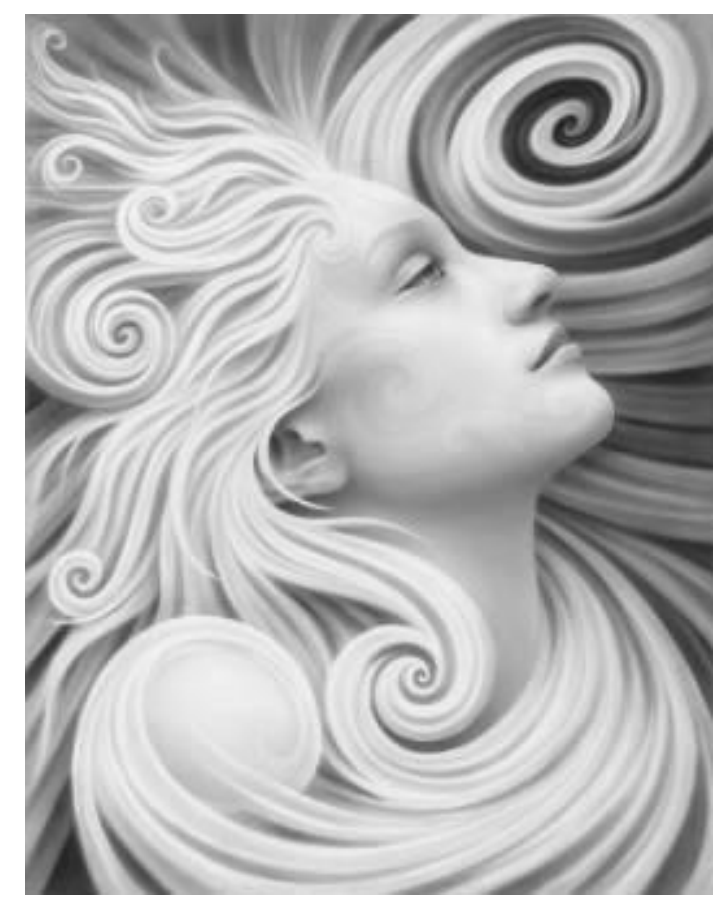

Figure 9. Spiral Reverie. Andrew Gonzalez.

\section{Final words}

This essay attempted to point at the visual coincidences arising from nonordinary states of consciousness, emphasizing that the experiences may produce similar images in individuals all over the world; conversely, they may undergo variations and adaptations owing to the environment and local culture the individuals are immersed in.

This paper attempted, from the vast quantity of examples that would not fit here, to present a small sample of visual representations from the remote past and others by contemporary artists that are both illustrative and result from non-ordinary states of consciousness. In the same way that indigenous people can consider some geometrical patterns to be sacred, because they were "seen" through experiences of contact with other levels of reality, the "spiritual realm", science tries to investigate those religious phenomena not as merely hallucinatory reveries, but as result of legitimate experiences, regardless of any evidence of the existence of such realms. Nowadays, the very nature of hallucination is being questioned, considering that because they do not exist in the material objective world, it does not mean that they cannot be part of a perfectly normal human psyche, thus presenting recurrent characteristics that are measurable by science. The visual representations, examined in an interdisciplinary way with human and 
biological sciences, help us to understand some evidence regarding the choice of certain geometric patterns used in the representations, as well as their modification and sophistication in more complex societies.

\section{References}

BRESSLOFF, P.C.; COWAN J.D.; GOLUBITSKY, M.; THOMAS, P.J. \& WIENER, M.C. Geometric Visual Hallucinations: Euclidean symmetry and the functional architecture of striate cortex. Philosophical Transactions of the Royal Society B: Biological Sciences, Volume 356, Number 140729 March, 2001. pp.299-330.

CAMPBELL, J. O Poder do Mito, São Paulo: Palas Athena,1991.

CARUANA, L. I Am the True Vine the Ayahuasca the Vine of the Dead. Available from: <http://www.lcaruana.com/webtext/mort.html>. [18 June 2014].

CHEVAliER, J. \& GHEERBRANT, A. Dicionário de Símbolos - Mitos, Sonhos, Costumes, Gestos, Formas, Figuras, Cores, Números. Rio de Janeiro: Editora José Olympio, 1999.

ELIADE, M. O Xamanismo e as Técnicas Arcaicas do Êxtase. São Paulo: Martins Fontes, 2002.

HANCOCK, G. Supernatural: meetings with the ancient teachers of mankind. New York: Disinformation Company Ltd, 2007.

HARNER, M. The Way of the Shaman: a guide to power and healing. New York: Bantam Books, 1982.

HOROWITZ, M.J. Hallucinations: An information-processing approach. In: Hallucinations. Behavior, experience, and theory. New York: Edited by Siegel RK, West LJ, Grune \& Stratton, 1975.

HUXleY, A. As Portas da Percepção - Céu e Inferno. São Paulo: Globo S.A., 2004.

KLÜVER, H. Mescal and Mechanisms of Hallucination. Chicago: University of Chicago, 1966.

LEWIS-WILliaMS, D. The Mind in the Cave: Consciousness and the Origins of Art. London: Thames \& Hudson, 2004.

LEWIS-WILLIAMS, D. \& PEARCE, D. Inside The Neolithic Mind: Consciousness, Cosmos and the Realm of the Gods. London: Thames \& Hudson, 2005.

MIKOSZ, J.E. Arte Visionária - Representações Visuais Inspiradas nos Estados Não Ordinários de Consciência (ENOC). Curitiba: Editora Prismas, 2014.

REICHEL-DOLMATOFF, G. O Contexto cultural de um alucinógeno aborígene: Banisteriopsis caapi. Available from: http://repositorio.ispa.pt/handle/10400.12/1944>. [21 June 2014]. 
Aprovado: 30/06/2015

Approved: 06/30/2015 